DOI: 10.46340/eujem.2020.6.6.14

Oleksii Koval

ORCID ID: https://orcid.org/0000-0002-3790-0331

Bohdan Khmelnytsky National University of Cherkasy, Ukraine

Alina Shevchenko

ORCID ID: https://orcid.org/0000-0002-3551-0372

Bohdan Khmelnytsky National University of Cherkasy, Ukraine

\title{
STRATEGIC RISK MANAGEMENT \\ IN THE SYSTEM OF PROVIDING BUSINESS ENTITIES FINANCIAL AND ECONOMIC SECURITY
}

The theoretical and methodological framework of strategic risk management in the system of financial and economic security of economic entities has been updated. The definition of strategic risk management from the standpoint of ensuring financial and economic security has been clarified. The necessity of strategic management of the enterprise to be carried out in combination with the tools of risk management, management of financial and economic security, personnel management is substantiated. The strategic risks for modern business entities are specified that can affect their financial and economic results in the long run. Approaches to strategic risk management in the system of financial and economic security of business structures are offered. Key words: strategic management, financial and economic security, risk, strategy, strategic risk.

Introduction. Issues of strategic management of various aspects of enterprises in conditions of uncertainty have recently attracted increasing attention of the scientific community. In a high-risk environment of domestic businesses, it is becoming increasingly difficult for top management to predict trends in operating conditions, and, accordingly, to plan targets and to build vectors to meet the interests of different categories of business stakeholders. Combining strategic management with approaches and practices to ensure financial and economic security at the micro level is an important and difficult task for classical management paradigms. On the one hand, managers need to develop a set of solutions to ensure the development of the enterprise, institution, organization in the future, and on the other hand there is a need to maximize the available potential to protect corporate resources from the negative impact of internal and external dangers and threats and counter the risks occurrence. Finding a balance between the distribution of time, labor, financial, material, information and other resources of the business entity for the purpose of qualitative evolution of economic processes, gaining new competitive advantages, entering new markets, innovation and expansion of customer network and their reservation for security financial and economic security, ie to achieve a certain static state of protection of the enterprise from the destructive effects of the challenges of the environment of its operation - is a very complex management task, the solution of which should begin in the field of scientific research.

Target setting. The purpose of the study is to update the theoretical and methodological framework of strategic risk management in the system of financial and economic security of economic entities. To achieve this goal it is necessary to solve a number of important research tasks: to clarify the definition of strategic risk management from the standpoint of financial and economic security, to specify strategic risks for modern economic entities that can affect their financial and economic results in the long run, to offer approaches to strategic risk management in the system of financial and economic security of business structures.

Analysis of recent research and publications. Problematic aspects of strategic management of economic entities of various types of economic activity are studied by many well-known domestic and foreign scientists. Researchers of security problems in recent years are increasingly active in preparing and publishing the results of their scientific and methodological work to address the problem of financial and economic security of enterprises, institutions and organizations. Also, a large number of scientific papers are devoted to the peculiarities of the application of domestic and foreign experience in the field of risk management. However, there are not many interdisciplinary studies that would combine the issues of strategic, security- 
oriented and risk management, or at least two of the three mentioned areas of management of modern business structures. Thus, among Ukrainian researchers, approaches to risk management and financial and economic security are combined by Zachosova N., Herasymenko O., Shevchenko A., Babina N., Zanora V., Kovalenko A. Kutsenko D. ${ }^{1}$ within the concretization of the theoretical foundations of financial and economic security management at the present stage of development of security science offers guidelines for strategic management of financial and economic security of enterprises, taking into account the interests, challenges and risks ${ }^{2}$, that accompany both the activities of the entity and directly the management process of the business structure. It should be emphasized that one of the authors of this study has already begun attempts to generalize the theoretical aspects of strategic management of the economic security system of economic entities $^{3}$, which is an evidence of awareness and consistency in the conduct of scientific research on the stated issues. Foreign scientists have also repeatedly tried to establish the features of financial and economic security management and risk management at the micro and macro levels ${ }^{4}$. The given factual material serves as a confirmation of the fact that currently there are scientific and methodological gaps in addressing the issue of effective strategic risk management in the system of financial and economic security of economic entities, which indicates the relevance of the chosen research topic.

Research results and discussion. In economic theory, strategic management is understood as a set of classical management functions, such as planning, organization, motivation, control, etc., aimed at achieving long-term goals of the entity. In this context, we should talk about the potential of the enterprise, because it is additional opportunities, those resources that may appear in the future due to skillful management and use of assets of the business structure, will allow to realize its economic interests and the interests of its stakeholders in the future. At the same time, irrational, short-sighted management decisions aimed solely at meeting current economic needs, for example, to maximize profits at a particular time, regardless of the potential benefits that may give the company other business alternatives that can cause financial and economic damage. Another aspect of strategic management is to take into account the impact of risks on the ability of the entity to achieve long-term goals. Identification of strategic risks, their analysis and assessment, as well as the development of measures to counteract their negative impact on corporate resources and search for sources of compensation for their consequences - are important and complex management tasks the top management of domestic enterprises, institutions and organizations are facing now. Risk management is a set of management decisions that are aimed at timely identification, specification, systematization, evaluation and control of real and probable factors that may have a negative impact on the state and results of the enterprise. These tasks are identical to those that modern scientists give to the process of financial and economic security of the entity management. However, we would like to note two important facts. First, the risk for the company can have both economically negative and positive consequences, because the existence of risk in itself is an objective reality for the functioning of all participants in economic relations, so effective risk management must have two vectors - the first - aimed at counteracting the negative consequences

\footnotetext{
${ }^{1}$ Zachosova, N., Herasymenko, O., Shevchenko A. (2018). Risks and possibilities of the effect of financial inclusion on managing the financial security at the macrolevel. Investment Management and Financial Innovations, 15, 4, 304-319; Zachosova, N., Babina, N., Zanora, V. (2018). Research and methodological framework for managing the economic security of financial intermediaries in Ukraine. Banks and Bank Systems, 13, 4, 119-130; Zachosova, N., Babina, N., Zanora, V. (2018). Research and methodological framework for managing the economic security of financial intermediaries in Ukraine. Banks and Bank Systems, 13, 4, 119-130; Занора, В. О. (2011). Експертний метод аналізу ризиків промислового підприємства. Управління проектами та розвиток виробництва, 2, 99-105; Kovalenko, A. (2019). Determinants of personnel policy in the process of management of financial and economic security of business entities. Bulletin of the Cherkasy University. Economic Sciences, 3, 70-77; Носань, Н. С., Куценко, Д. М. (2019). Теоретичні засади управління фінансово-економічною безпекою на сучасному етапі розвитку безпекознавства. Вісник Черкаського національного університету імені Богдана Хмельницького. Серія Економічні науки, 1, 76-83.

${ }^{2}$ Kutsenko, D. (2019). Orienters of strategic management of financial and economic security of enterprises: interests, challenges, risks. Bulletin of the Cherkasy Bohdan Khmelnytsky National University. Economic Sciences, $2,50-58$. ${ }^{3}$ Koval, O. V. (2020). Strategic management of economic security system of business entities: theoretical aspects. Bulletin of the Cherkasy National University. Economic Sciences, 1, 40-47.

${ }^{4}$ Kahler, M. (2004). Economic Security in an Era of Globalization: Definition and Provision. Journal The Pacific Review, 17/4, 485-502; Dyakonova, I., Nikitina, A., Gurvits, N. (2018). Improvement of the Enterprise Economic Security Management in Global Environment. Geopolitics under Globalization, 2 (1), 19-26; Black, S. E., Devereux, P. J., Lundborg, P., Majlesi, K. (2018). Learning to Take Risks? The Effect of Education on Risk-Taking in Financial Markets. Review of Finance, 22/3, 951-975.
} 
of the existence of risks, the second - to obtain a positive effect from the realization of opportunities that lie behind the decision to take risks in a particular economic situation. The second fact is that the management of financial and economic security at the micro level is not limited to the risks identification, monitoring and control. This is a range of actions, which also includes: achieving a balance of interests between different categories of stakeholders to direct the company's resources to protective measures, current activities and development of the entity with mandatory analysis of threats and risks for the last two of these three alternatives; organization of physical and digital protection of business structure assets; formation of relevant information support on the negative factors of the internal and external environment of the enterprise for making informed management decisions; development of a policy of security-oriented transparency of the company's activities, as well as security-oriented personnel policy.

There is an approach according to which strategic management is based on the human resources of the enterprise, and its characteristic feature is the flexibility of reactions to changes in the environment of the economic structure. Despite the rationality of such a paradigm, we must recognize that in domestic realities such characteristics of strategic management are not inherent in it. Thus, the top management gives priority to care for financial resources rather than human resources, and even more so, and attention to the development of human resources - is not the mainstream of Ukrainian type of management. The flexibility of strategic management is constrained by the high level of bureaucratization of management decisions, as well as the complexity of subordination relations in the organizational structures of domestic enterprises. The review of companies' strategies, if such a need is finally realized by top management, takes a long time, requires numerous approvals at various levels of management. Therefore, the problematic aspects of strategic management are the erroneousness of the chosen strategic guidelines, unrealistic planned performance indicators, the impossibility of prompt changes and adjustments, neglect of existing and potential risks and opportunities for their use for the benefit of the company and its stakeholders, financing of financial and economic security measures on a residual basis.

Under the strategic risk management from the standpoint of financial and economic security, we offer to understand the process of anticipating potential risks that will be characteristic of the company in the future given its course to achieve specific strategic goals based on the identification of risks for its activities; their cataloging and forecasting their probable both positive and negative impact on the economic condition of the business entity and the development of methods for managing them by means of financial and economic security to minimize their undesirable consequences for the integrity and efficiency of corporate resources. The offered definition is not intended to identify the process of planning and strategic management, but is aimed at emphasizing the fact that the distinguishing feature of strategic management from operational management is the orientation of management decisions on future achievements of the enterprise. Therefore, the element of foresight is important for the organization of effective strategic management.

Critics may point out that the proposed definition demonstrates a fairly conditional link between strategic management and the financial and economic security of an entity. It should be noted, however, that a high level of financial and economic security should be recognized as one of the mandatory elements of the general strategy of any enterprise, institution, organization. Security-oriented management is gaining popularity around the world. Awareness of the critical growth of risks in the global and local economic systems has led to top management's review of business guidelines for maximizing profitability at any cost to the balance of profits and costs of security measures, which ensures the continued operation of the entity in the long run perspective with moderate but long-term and constant profitability. This model is more socially oriented, successful in terms of state regulation of the economy and fully meets the goals of sustainable development, which have gained worldwide support.

Strategic risk management in the system of financial and economic security of economic entities should rationally begin with the specification of the list of strategic risks that have or can potentially affect the results of enterprises. Strategic risks are directly related to the strategic goals of the business structure, and can be divided into two major groups: risks that prevent the achievement of strategic goals of the enterprise and risks of incorrect strategy of the enterprise on the vectors of its financial, investment, innovation, marketing and other activities. The second group includes the risk of errors in establishing strategic goals of the financial and economic security of the entity, which can lead to overuse of resources, low efficiency of the chosen means of protection of assets of the enterprise, and untimely adoption of necessary security-oriented management decisions.

The cost of the wrong management decision to respond to strategic risks can be very high. Incorrect assessment of strategic risk and its consequences can lead to the loss of the company's own market niche, a 
significant reduction in the level of competitiveness and even bankruptcy and liquidation. In addition, the impact of strategic risks is prolonged over time: their effect is intensified, then disappears completely, which can mislead the risk manager; their manifestation may be invisible at the beginning of the strategy, and already in the middle of the enterprise to the desired goal to become so tangible that the management of the entity will have to review their strategic guidelines and means to achieve them, seek additional resources, change the model of the chosen strategy, etc. Financial and economic strategic risks can have different sources of origin. Their emergence is provoked by changes in equipment and technology, which is quite relevant for the period of spread of Industry 4.0 trends, changes in financing conditions of the enterprise, termination of access to investment resources or the emergence of new, untested sources of their income, personnel dishonesty, including insiders, raiding attempts to attack, takeovers and alliances, etc. It is possible to offer such an oriented list of strategic risks for financial and economic security, which is universal for business entities of different types of economic activity:

- the appearance substitute goods (or analogue services) that are cheaper and meet a wider range of consumer needs in the market;

- appearance of new competitors (for example, European companies) with a high level of business reputation and a world-famous brand in the market;

- change in prices for key resources, raw materials, materials, components;

- the need for temporary cessation of financial and economic activities or its rapid adaptation to new conditions (for example, in a pandemic situation and the establishment of quarantine restrictions);

- change in exchange rates (this risk is especially significant for importers and exporters of goods and services);

- the emergence of innovations and know-how that will require a radical transformation of economic processes;

- change of state policy in the field where the business entity operates;

- digitalization of economic relations in various fields.

It is necessary to identify strategic risks and look for effective methods and ways to counteract their negative impact on management at the stage of developing or choosing a strategy for the enterprise in general and ensuring its financial and economic security in particular, as well as to implement strategies through mechanisms of dynamic change of its individual provisions to new challenges of the business environment of the business entity.

Based on the results of the study, the following approaches to strategic risk management in the system of financial and economic security of business structures can be offered (Table 1).

Choosing a specific approach for an individual entity is the prerogative and task of its top management, for the results of which management will have to bear full responsibility for the owners of companies and its stakeholders.

Conclusions. The study of the features of strategic risk management in the system of financial and economic security of economic entities allowed to draw the following conclusions.

1. Clarification of the definition of strategic risk management from the standpoint of financial and economic security allowed to present its content as a process of anticipating potential risks that will be characteristic of the company in the future given its course to achieve specific strategic guidelines based on identifying risks; their cataloging and forecasting their probable both positive and negative impact on the economic condition of the entity and the development of methods for managing them by means of financial and economic security to minimize their undesirable consequences for the integrity and efficiency of corporate resources.

2. The concretization of strategic risks for modern business entities that can affect their financial and economic results in the long run, allowed to form the following list: the appearance on the market of substitute goods (or analogue services) that are cheaper and more satisfying a wide range of consumer needs; emergence of new competitors (for example, European companies) with a high level of business reputation and a worldfamous brand; change in prices for key resources, raw materials, materials, components, etc.; the need for temporary cessation of financial and economic activities or its rapid adaptation to new conditions (for example, in a pandemic and the establishment of quarantine restrictions); change in exchange rates (this risk is especially significant for importers and exporters of goods and services); emergence of innovations and know-how that will require a radical transformation of economic processes; change of state policy in the field of enterprise functioning; digitalization of economic relations in various fields, etc. 
Approaches to strategic risk management in the system of financial and economic security of economic entities

\begin{tabular}{|c|c|c|}
\hline $\begin{array}{l}\text { The name } \\
\text { of the approach }\end{array}$ & Advantages & Disadvantages \\
\hline $\begin{array}{l}\text { Active risk } \\
\text { management }\end{array}$ & $\begin{array}{l}\text { Existence of risk management strategy; } \\
\text { formation of the budget for risk-oriented actions } \\
\text { financing; risk management - the basic method } \\
\text { of security maintenance; the general strategy is } \\
\text { created taking into account existing and } \\
\text { potential strategic risks }\end{array}$ & $\begin{array}{l}\text { Significant financial costs of preventing } \\
\text { events that may or may not occur, } \\
\text { focusing on the negative consequences } \\
\text { that risks may have for the state of } \\
\text { financial and economic security }\end{array}$ \\
\hline $\begin{array}{l}\text { Passive risk } \\
\text { management }\end{array}$ & $\begin{array}{l}\text { Insignificant costs of financial, information, } \\
\text { human and time resources; use of risk } \\
\text { management models that have proven their } \\
\text { effectiveness for other economic structures }\end{array}$ & $\begin{array}{l}\text { Responding to risk and its consequences } \\
\text { only at the moment of their manifestation; } \\
\text { lack of a catalog of decisions on risk } \\
\text { allocation or transfer, giving preference to } \\
\text { risk avoidance, which limits business } \\
\text { opportunities }\end{array}$ \\
\hline $\begin{array}{l}\text { Project risk } \\
\text { management }\end{array}$ & $\begin{array}{l}\text { Management of specific significant risk as a } \\
\text { separate project with the formation of a } \\
\text { professional team and the provision of } \\
\text { necessary resources; when risk is absent, } \\
\text { resources are directed to the realization of the } \\
\text { main goals of the enterprise }\end{array}$ & $\begin{array}{l}\text { Slow response to risk and its consequences } \\
\text { due to the need to develop a project and to } \\
\text { prepare for its implementation, the need } \\
\text { for knowledge and skills of project } \\
\text { management; situational nature of risk } \\
\text { management }\end{array}$ \\
\hline $\begin{array}{l}\text { Externally oriented } \\
\text { risk management }\end{array}$ & $\begin{array}{l}\text { Prevention and constant control of external } \\
\text { factors that may adversely affect financial and } \\
\text { economic security; involvement of professional } \\
\text { outsiders in the risk management process }\end{array}$ & $\begin{array}{l}\text { Ignoring the risks of the internal } \\
\text { environment }\end{array}$ \\
\hline $\begin{array}{l}\text { Internally oriented } \\
\text { risk management }\end{array}$ & $\begin{array}{l}\text { Focusing on the development of the potential of } \\
\text { the business entity; close attention and } \\
\text { monitoring of business processes; identification } \\
\text { and control of personnel risks }\end{array}$ & $\begin{array}{c}\text { Ignoring the risks of the external } \\
\text { environment }\end{array}$ \\
\hline $\begin{array}{l}\text { Mixed risk } \\
\text { management }\end{array}$ & $\begin{array}{l}\text { All the advantages of the approaches, methods } \\
\text { and techniques of which are combined }\end{array}$ & $\begin{array}{l}\text { All the disadvantages inherent in the } \\
\text { approaches, methods and techniques of } \\
\text { which are combined }\end{array}$ \\
\hline
\end{tabular}

Source: developed by the authors.

3. The following approaches to strategic risk management in the system of financial and economic security of business structures can be offered: active risk management, passive risk management, project risk management, externally oriented risk management, internally oriented risk management, mixed risk management. Each of these approaches has its own advantages and disadvantages, and therefore the choice of a specific approach for the needs of an individual entity should be determined on the basis of analysis of trends in its environment and taking into account its financial condition, performance and state of financial security.

We see prospects for further research in assessing strategic risks for the state of financial and economic security of various types of business structures, forming maps of strategic risks and developing catalogs of management decisions to counter them in optimistic, realistic and pessimistic scenarios.

\section{References:}

1. Zachosova, N., Herasymenko, O., Shevchenko, A. (2018). Risks and possibilities of the effect of financial inclusion on managing the financial security at the macrolevel. Investment Management and Financial Innovations, 15, 4, 304-319. [in English].

2. Zachosova, N., Babina, N., Zanora, V. (2018). Research and methodological framework for managing the economic security of financial intermediaries in Ukraine. Banks and Bank Systems, 13, 4, 119-130. [in English].

3. Zanora, V. O. (2011). Ekspertnyy metod analizu ryzykiv promyslovoho pidpryyemstva [Expert method of risk analysis of an industrial enterprise]. Upravlinnya proektamy ta rozvytok vyrobnytstva [Project management and production development], 2, 99-105 [in Ukrainian]. 
4. Kovalenko, A. (2019). Determinants of personnel policy in the process of management of financial and economic security of business entities. Bulletin of the Cherkasy University. Economic Sciences, 3, 70-77. [in English].

5. Nosan, N. S., Kutsenko, D. M. (2019). Teoretychni zasady upravlinnya finansovo-ekonomichnoyu bezpekoyu na suchasnomu etapi rozvytku bezpekoznavstva [Theoretical principles of financial and economic security management at the present stage of security science development]. Visnyk Cherkaskoho natsionalnoho universytetu imeni Bohdana Khmelnytskoho. Seriya Ekonomichni nauky [Bulletin of the Cherkasy Bohdan Khmelnytsky National University. Economic Sciences], 1, 76-83. [in Ukrainian].

6. Kutsenko, D. (2019). Orienters of strategic management of financial and economic security of enterprises: interests, challenges, risks. Bulletin of the Cherkasy Bohdan Khmelnytsky National University. Economic Sciences, 2, 50-58. [in English].

7. Koval, O. V. (2020). Strategic management of economic security system of business entities: theoretical aspects. Bulletin of the Cherkasy National University. Economic Sciences, 1, 40-47. [in English].

8. Kahler, M. (2004). Economic Security in an Era of Globalization: Definition and Provision. Journal The Pacific Review, 17/4, 485-502. [in English].

9. Dyakonova, I., Nikitina, A., Gurvits, N. (2018). Improvement of the Enterprise Economic Security Management in Global Environment. Geopolitics under Globalization, 2 (1), 19-26. [in English].

10. Black, S. E., Devereux, P. J., Lundborg, P., Majlesi, K. (2018). Learning to Take Risks? The Effect of Education on Risk-Taking in Financial Markets. Review of Finance, 22/3, 951-975. [in English]. 